\title{
Growth performance and haematology of broiler chickens fed enzyme supplemented neem leaf meal -based diets
}

Akintomide, A. A., Osho, I. B. and Onibi, G. E.

Department of Animal Production and Health,

Federal University of Technology, Akure, Ondo State, Nigeria.

Abstract

*Corresponding author: aakintomide@futa.edu.ng; 08036110363

The quest for sustainable poultry production using alternative feed ingredients is imperative. This study was conducted to assess the growth performance and blood profile of broiler chickens fed neem leaf meal (NLM) based diets with or without enzyme supplementation. Two hundred and eighty-eight, one-week old chicks (with an average weight of 98.44g) arranged in a completely randomized design with twelve birds/ replicate and three replicates/ treatment were fed NLM at 0, 1.5, 3 and 5\% with or without Polyzme ${ }^{\circledR}$ to form eight experimental treatments. Data on initial body weights, weekly body weights and feed intake were taken during the trial which lasted for eight weeks and feed conversion ratio calculated. Blood was also collected for haematological studies at the $4^{\text {th }}$ and $8^{\text {th }}$ week by humanely severing the jugular vein. Results indicated that total weight gain at starter phase decreased progressively with increase in NLM inclusion and addition of Polyzme did not significantly $(P>0.05)$ affect performance. At the finisher phase, growth performance was not significantly $(P>0.05)$ influenced by NLM or enzyme addition. Furthermore, NLM with/without Polyzyme did not elicit any significant influence on the packed cell volume and haemoglobin concentration of the chickens. In conclusion, broiler chicks could tolerate up to $3 \%$ NLM and finishers up to 5\% based on growth performance. The use of polyzyme at $400 \mathrm{~g} /$ tonne in this study did not improve the utilization of NLM by the chickens.

Keywords: Alternative feed ingredients, Polyzyme, Blood profile, Broiler feed, Exogenous enzyme

\section{Performances de croissance et hématologie des poulets à griller nourris avec des régimes à base de farine de feuilles de neem enrichis d'enzymes}

\section{Résumé}

La recherche de la production de volaille durable utilisant des ingrédients d'alimentation alternatifs est impérative. Cette étude a été réalisée pour évaluer la performance de la croissance et le profil sanguin des régimes à base de feuilles neem (NLM) avec ou sans supplémentation en enzyme. Deux cent quatre-vingt-huit poussins âgés d'une semaine (avec un poids moyen de 98,44 g) disposés dans un design complètement randomisé avec douze oiseaux / répliqués et trois répliqués / traitement ont été nourris à $0,1,5,3$ et $5 \%$ avec ou sans Polyzme pour former huit traitements expérimentaux. Les données sur les poids corporels initiaux, les poids corporels hebdomadaires et l'apport alimentaire ont été pris au cours de l'essai qui a duré huit semaines et le ratio de conversion alimentaire calculé. Le sang a également été collecté pour des études hématologiques à la 4ème et 8ème semaine en coupant humainement la veine jugulaire. Les résultats ont indiqué que le gain de poids total à la phase de démarrage a diminué progressivement avec l'augmentation de l'inclusion de NLM et l'addition de polyzme n'a pas significativement ( $p>0,05)$ affecter les performances. A la phase de finition, la performance de la croissance n'était pas significativement $(p>0,05)$ influencée par l'addition NLM ou enzyme. De plus, la NLM avec/sans polyzyme n'a suscité 
aucune influence significative sur le volume de la cellule emballé et la concentration en hémoglobine des poulets. En conclusion, les poussins de chair pourraient tolérer jusqu'à 3\% de NLM et des finisseurs jusqu'à 5\% sur la base de la performance de la croissance. L'utilisation de polyzyme à $400 \mathrm{~g} /$ tonne dans cette étude n'a pas amélioré l'utilisation de NLMpar les poulets.

Mots-clés: Ingrédients d'alimentation alternatifs, Polyzyme, Profilé de sang, Flux de gril, Enzyme exogène

\section{Introduction}

When considering provision of affordable animal protein especially for the low income group, rearing of poultry would readily come to mind (Allouche et al., 2015). And in order to ensure fast and optimum growth of chickens, giving them a well-balanced ration is highly essential. Albeit, scarcity of major feed ingredients (Adebayo and Adeola, 2005) like maize and soybeans, and increase in prices of commercial finished feeds due to unfavourable government policies and disease outbreaks have posed a serious challenge to the industry. The search for alternative feed ingredients such as agroindustrial byproducts (Ajila et al., 2012; Fabunmi et al., 2019) and leaf meals (Fasuyi, 2007; Hien et al., 2017) have been intensified recently so as to keep the poultry industry from collapse. Furthermore, to cushion the high cost of feed ingredients, the addition of exogenous enzymes would be beneficial as it should lead to increased utilization of nutrients in compounded or finished feeds. Feed ingredients which contain considerable amounts of antinutrients can be better utilized as exogenous enzymes mitigate their adverse effects, one of which is inhibition of digestive enzymes (Alam et al., 2003). Better utilization of nutrients in these feed ingredients results in better performance of the animals as shown by Costa et al., 2008 and Allouche et al., 2015, which invariably leads to increased profit for the farmer. Alam et al. (2003) tested the efficacy of three commercial enzymes in the feed of broiler chickens and the results showed that one of the enzymes did not improve the utilization of feed as the other two enzymes. Also, according to Bedford and Schulze (1998), the response of birds to xylanase, $\beta$ glucanase and phytase vary. This suggests variations in responses of chickens to exogenous enzymes. Other researchers have also used enzymes successfully in animal feed (Allouche et al., 2015). Ogunsipe et al., 2015 concluded that when cassava plant meal was supplemented with Roxazyme G2G, it could be used up to $40 \%$ in broiler diet. Allouche et al. (2015) supplemented a low energy broiler diet with enzyme and the resulting effect was increased profit due to better feed utilization by the chickens which was the effect of concomitant reduction in feed intake by the birds. Neem leaves contains a good amount of protein, mineral and vitamins although, it is high in fibre which is a typical characteristic of leaves. The antibacterial, anticoccidial, antioxidant and hepatoprotective abilities of neem leaves are also well documented (Sithisarn et al., 2005; Kumar et al., 2010). Adesua (2019) noted that broilers were able to tolerate 5\% neem leaf meal (NLM). Owing to the documented health benefits of NLM, this study was carried out to assess the response of broiler chickens to supplementation of diets which contained NLM at lower levels with Polyzyme using growth indices and haematology as response criteria.

\section{Materials and methods}

\section{Experimental site}

This trial was carried out at the Poultry Unit, Teaching and Research Farm, Federal University of Technology, Akure, Ondo 153 
between latitude $7^{\circ} 5$ ? $\mathrm{N}$ and longitude $5^{\circ} 15$ ? E at an altitude of $370 \mathrm{~m}$ above sea level (Oyinloye, 2013).

\section{Experimental treatments}

Neem leaf meal (NLM) was included in broiler rations at $0,1.5,3.0$ and $5.0 \%$ with or without Polyzyme ${ }^{\circledR}$ supplementation to form 8 experimental treatments. The compositions of diets at starter and finisher phases are presented in Tables 1 and 2 .

Experimental birds and management practices

Three hundred and fifty (350) day-old Marshal broiler chicks were purchased from a reputable farm at Ibadan, Oyo State,
Nigeria. The $1^{\text {st }}$ week was a preexperimental period after which 288 birds were randomly allocated to the treatments (3 replicates/treatment; 12 birds/replicate). Data on initial body weights, weekly body weights and feed intake were taken appropriately during the trial. Feed conversion ratio was calculated as feed intake divided by weight gain. Two birds/ replicate were humanely slaughtered at the end of starter phase and three at the end of finisher phase. Birds were put under good hygienic conditions throughout the experimental period. Experimental diets and water were supplied ad libitum and

Table 1: Compositions of neem leaf meal diets for broiler-chicken starters with/without polyzyme supplementation

\begin{tabular}{|c|c|c|c|c|}
\hline \multirow[t]{2}{*}{ Ingredients (kg) } & \multirow[b]{2}{*}{ Control (0) } & \multicolumn{3}{|c|}{ Level of inclusion (\%) } \\
\hline & & 1.5 & 3.0 & 5.0 \\
\hline Maize & 53.00 & 52.50 & 51.50 & 50.00 \\
\hline Neem Leaf Meal & 0.00 & 1.50 & 3.00 & 5.00 \\
\hline Wheat offal & 8.80 & 7.80 & 7.80 & 7.80 \\
\hline Soyabean meal & 16.00 & 16.00 & 16.00 & 16.00 \\
\hline Groundnut cake & 16.00 & 16.00 & 15.50 & 15.00 \\
\hline Fish meal $(72 \%)$ & 3.00 & 3.00 & 3.00 & 3.00 \\
\hline Bone meal & 2.10 & 2.10 & 2.10 & 2.10 \\
\hline Oyster shell & 0.20 & 0.20 & 0.20 & 0.20 \\
\hline Lysine & 0.10 & 0.10 & 0.10 & 0.10 \\
\hline Methionine & 0.25 & 0.25 & 0.25 & 0.25 \\
\hline Premix* & 0.25 & 0.25 & 0.25 & 0.25 \\
\hline Table salt & 0.30 & 0.30 & 0.30 & 0.30 \\
\hline Total & 100 & 100 & 100 & 100 \\
\hline \multicolumn{5}{|l|}{ Calculated analysis } \\
\hline $\mathrm{ME}(\mathrm{Kcal} / \mathrm{Kg})$ & 2923.72 & 2944.00 & 2952.61 & 2962.78 \\
\hline Crude protein $(\%)$ & 22.57 & 22.69 & 22.71 & 22.80 \\
\hline Crude fibre (\%) & 3.68 & 3.80 & 3.97 & 4.20 \\
\hline Ether extract (\%) & 4.08 & 4.10 & 4.11 & 4.12 \\
\hline Calcium (\%) & 1.15 & 1.14 & 1.14 & 1.13 \\
\hline Phosphorus (\%) & 0.59 & 0.59 & 0.59 & 0.59 \\
\hline \multicolumn{5}{|c|}{ Analysed composition (\%) } \\
\hline Crude protein & 22.23 & 22.30 & 22.50 & 22.62 \\
\hline Crude fibre & 3.40 & 3.89 & 4.05 & 4.22 \\
\hline Ether extract & 4.33 & 5.12 & 5.23 & 5.69 \\
\hline Ash & 2.91 & 3.18 & 3.28 & 3.41 \\
\hline \multicolumn{5}{|c|}{$\begin{array}{l}\text { *2.5kg premix contains Vitamin A (8,000,000 I.U);Vitamin D3 (2,000,000 I.U); Vitamin E (5,000mg) } \\
\text { Niacin (15,000mg); Vitamin B1 (1,500mg); Vitamin B2 (8,000mg); Vitamin B6 (1,500mg), Vitamin } \\
\text { B12 (10mg); Vitamin K3 (2,000mg); Calpan (5,000mg); Biotin (20mg); Folic acid (500mg); } \\
\text { Antioxidant (125,000mg); Choline chloride (200,000mg); Cobalt (200mg); Copper }(5,000 \mathrm{mg}) \text {; Iodine } \\
(1,200 \mathrm{mg}) \text {; Iron (40,000mg); Manganese (80,000mg); Selenium (200mg); Zinc }(60,000 \mathrm{mg})\end{array}$} \\
\hline
\end{tabular}


vaccination done as scheduled.

\section{Haematological studies}

Blood samples for haematological studies were collected as described by Lamb (1981) and were immediately put into bottles containing EDTA as coagulant, capped and inverted repeatedly for about a minute to prevent clotting of blood samples.

\section{Statistical analysis}

All data generated were subjected to oneway and factorial analysis of variance (ANOVA) as appropriate. Where significant differences were found, means were compared using Tukey test of the Minitab Statistical Package (v 17).

Table 2: Composition of neem leaf meal diets for broiler-chicken finishers with/without polyzyme supplementation

\begin{tabular}{|c|c|c|c|c|}
\hline \multirow[t]{2}{*}{ Ingredients (kg) } & \multicolumn{4}{|c|}{ Level of inclusion (\%) } \\
\hline & Control (0) & 1.5 & 3.0 & 5.0 \\
\hline Maize & 52.50 & 52.00 & 51.50 & 51.30 \\
\hline Neem Leaf Meal & 0.00 & 1.50 & 3.00 & 5.00 \\
\hline Wheat offal & 13.00 & 12.00 & 11.40 & 8.00 \\
\hline Soyabean meal & 15.00 & 15.00 & 15.00 & 15.00 \\
\hline Groundnut cake & 13.90 & 13.90 & 13.50 & 15.10 \\
\hline Vegetable oil & 2.00 & 2.00 & 2.00 & 2.00 \\
\hline Bone meal & 2.40 & 2.40 & 2.40 & 2.40 \\
\hline Oyster shell & 0.20 & 0.20 & 0.20 & 0.20 \\
\hline Lysine & 0.20 & 0.20 & 0.20 & 0.20 \\
\hline Methionine & 0.25 & 0.25 & 0.25 & 0.25 \\
\hline Premix $*$ & 0.25 & 0.25 & 0.25 & 0.25 \\
\hline Table salt & 0.30 & 0.30 & 0.30 & 0.30 \\
\hline Total & 100 & 100 & 100 & 100 \\
\hline \multicolumn{5}{|l|}{ Calculated analysis } \\
\hline $\mathrm{ME}(\mathrm{Kcal} / \mathrm{Kg})$ & 2989.62 & 3009.90 & 3027.09 & 3073.74 \\
\hline Crude protein $(\%)$ & 19.79 & 19.90 & 19.91 & 20.48 \\
\hline Crude fibre $(\%)$ & 3.83 & 3.94 & 4.08 & 4.15 \\
\hline Ether extract $(\%)$ & 4.11 & 4.14 & 4.15 & 4.22 \\
\hline Calcium $(\%)$ & 1.03 & 1.05 & 1.06 & 1.08 \\
\hline Phosphorus (\%) & 0.50 & 0.53 & 0.53 & 0.57 \\
\hline \multicolumn{5}{|c|}{ Analysed composition (\%) } \\
\hline Crude protein & 19.21 & 20.89 & 19.37 & 19.89 \\
\hline Crude fibre & 4.23 & 5.16 & 5.98 & 6.05 \\
\hline Ether extract & 6.05 & 5.62 & 5.64 & 4.69 \\
\hline Ash & 2.91 & 4.81 & 4.28 & 4.41 \\
\hline \multicolumn{5}{|c|}{$\begin{array}{l}\text { *2.5kg premix contains Vitamin A (8,000,000 I.U);Vitamin D3 (2,000,000 I.U); Vitamin E (5,000mg), Niacin } \\
(15,000 \mathrm{mg}) \text {; Vitamin B1 (1,500mg); Vitamin B2 (8,000mg); Vitamin B6 (1,500mg), Vitamin B12 (10mg); Vitamin } \\
\text { K3 (2,000mg); Calpan (5,000mg); Biotin (20mg); Folic acid (500mg); Antioxidant (125,000mg); Choline chloride } \\
(200,000 \mathrm{mg}) \text {; Cobalt (200mg); Copper (5,000mg); Iodine (1,200mg); Iron (40,000mg); Manganese (80, } 000 \mathrm{mg}) \\
\text { Selenium (200mg); Zinc }(60,000 \mathrm{mg})\end{array}$} \\
\hline
\end{tabular}

\section{Results}

Table 3 shows the growth performance parameters of broiler chicks fed diets containing neem leaf meal (NLM) with or without polyzyme supplementation. The final weight, weight gain and feed conversion ratio (FCR) were significantly
$(\mathrm{P}<0.01)$ influenced by levels of NLM inclusion. Final weight $(\mathrm{g} / \mathrm{bird})$ and total weight gain (g/bird) decreased progressively with increasing addition of NLM. Although values recorded for $1.5 \%$ NLM did not vary significantly from control. For FCR, control had the best value 


\section{Akintomide, Osho and Onibi}

which increased with increasing NLM inclusion. Although, control, 1.5\% NLM and $3.0 \%$ NLM did not differ significantly. The effect of polyzyme supplementation was not significantly $(\mathrm{P}>0.05)$ different for the parameters measured.

Table 4 shows the growth performance parameters of broilers at the finisher phase. The initial weights recorded were as a result of the final weights of the birds at the starter phase. Significant differences were not also observed in all parameters based on level of NLM inclusion or polyzyme supplementation. The overall growth performance parameters of broiler chickens fed diets containing NLM with or without polyzyme supplementation are presented in Table 5. Based on the mean separation due to level of NLM included, all parameters were not significantly $(\mathrm{P}>0.05)$ different. Weight gain however seemed to decrease progressively with increasing level of NLM. No significant $(\mathrm{P}>0.05)$ difference was recorded in the growth performance parameters measured with or without polyzyme supplementation. Blood parameters of broiler chicks fed diets containing NLM with or without polyzyme supplementation are presented in Table 6 .
Addition of NLM to broiler chicks' diets did not elicit any significant $(\mathrm{P}>0.05)$ influence on packed cell volume (PCV), red blood cell count (RBC), haemoglobin concentration $(\mathrm{Hb})$, erythrocyte sedimentation rate (ESR), mean cell volume, mean cell haemoglobin, mean cell haemoglobin concentration, lymphocyte, heterophil, basophil and eosinophil values. Packed cell volume, RBC, Hb, ESR and basophil were significantly $(\mathrm{P}<0.05)$ influenced by polyzyme supplementation. Values recorded for these parameters were higher with polyzyme supplementation than without it. The PCV value for chicks fed polyzyme supplemented NLM diets was $27.92 \%$ while those without had $26.04 \%$. Red blood cell count and $\mathrm{Hb}$ values were also $4.78 \times 10^{6} \mathrm{~mm}^{3} ; 9.31 \mathrm{~g} / 100 \mathrm{~mL}$ and $3.79 \times 10^{6} \mathrm{~mm}^{3} ; 8.68 \mathrm{~g} / 100 \mathrm{~mL}$ with or without polyzyme supplementation respectively. Table 7 shows the blood parameters of broiler finishers fed diets containing NLM with or without polyzyme supplementation. Only the lymphocyte values varied significantly $(\mathrm{P}<0.05)$ with NLM inclusion. However, no significant $(\mathrm{P}>0.05)$ difference was observed in all parameters based on polyzyme supplementation. 


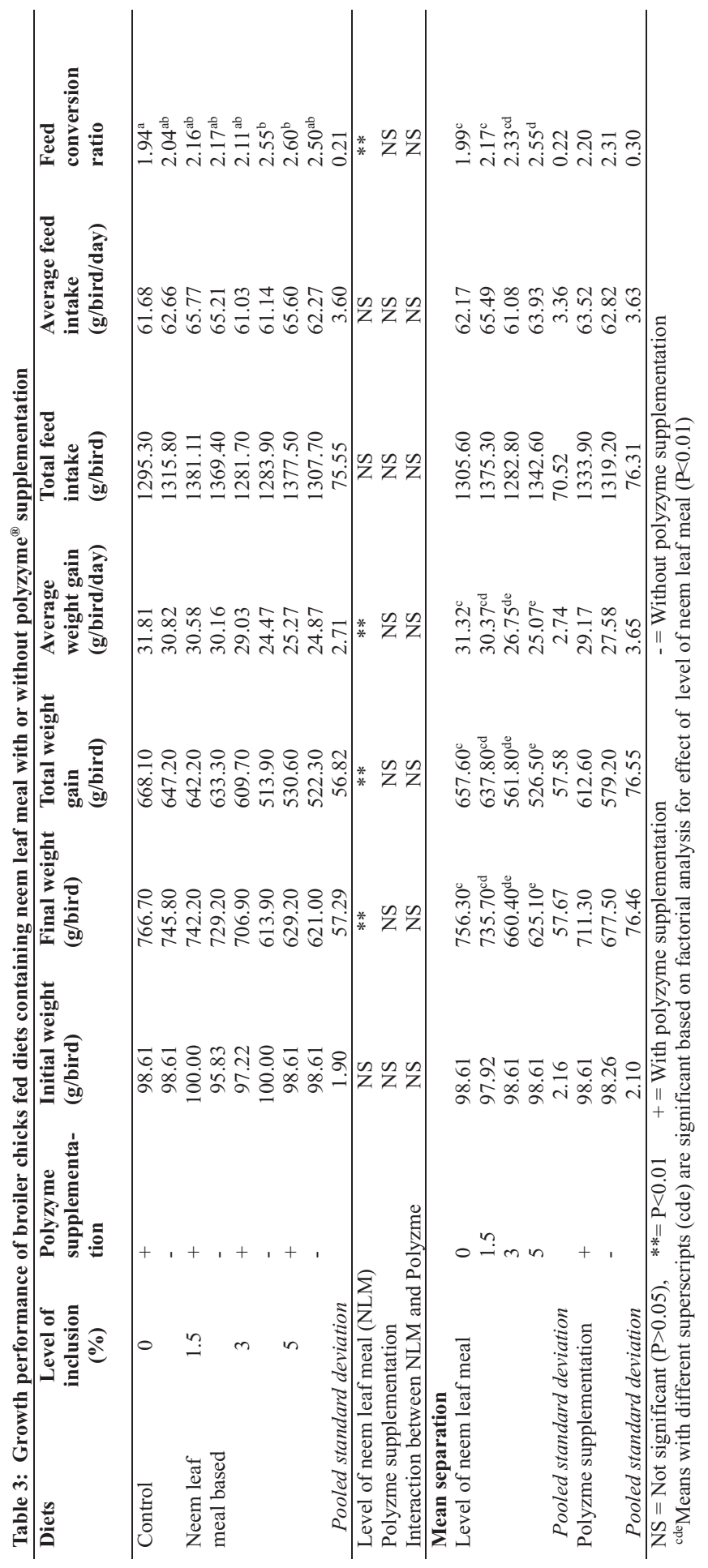


Akintomide, Osho and Onibi

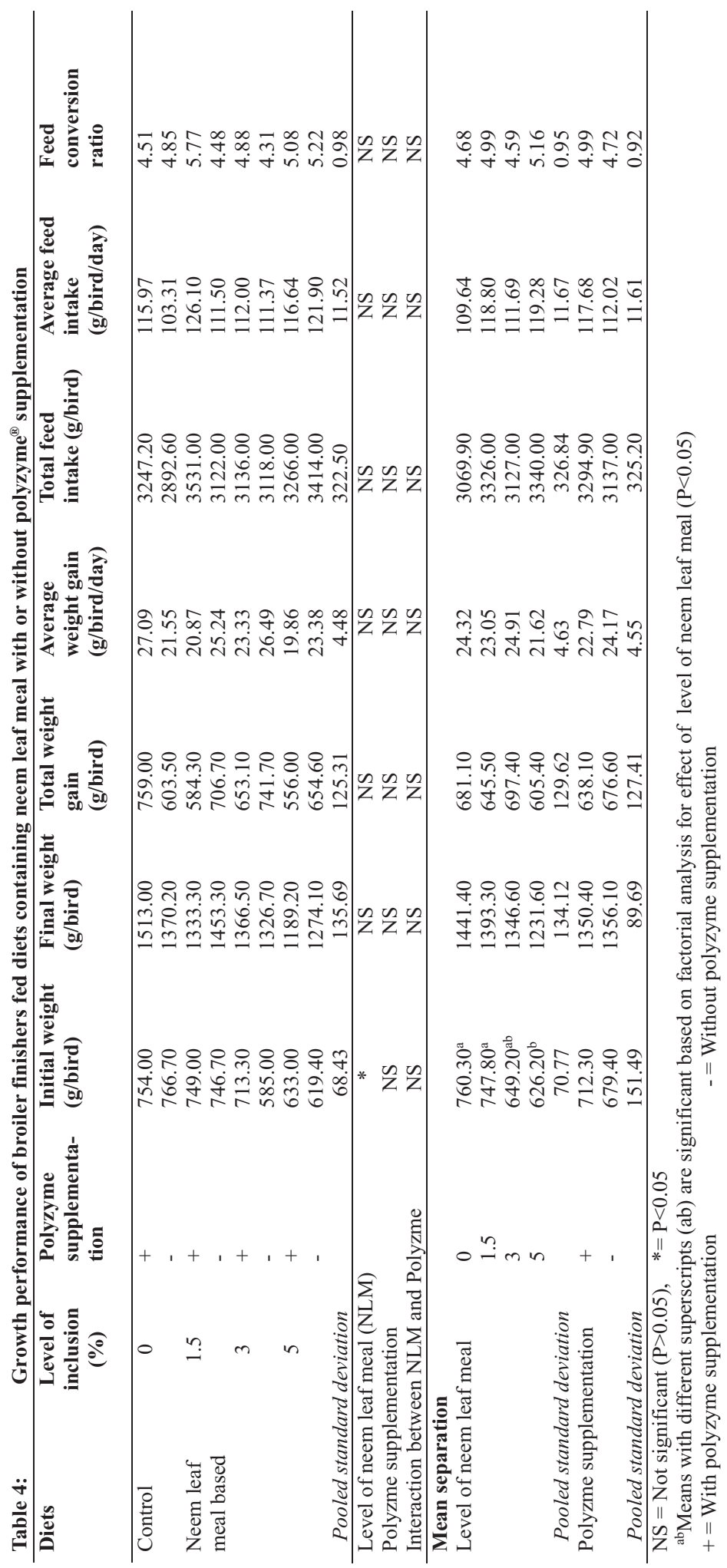


Growth performance and haematology of broiler chickens fed enzyme supplemented neem leaf meal

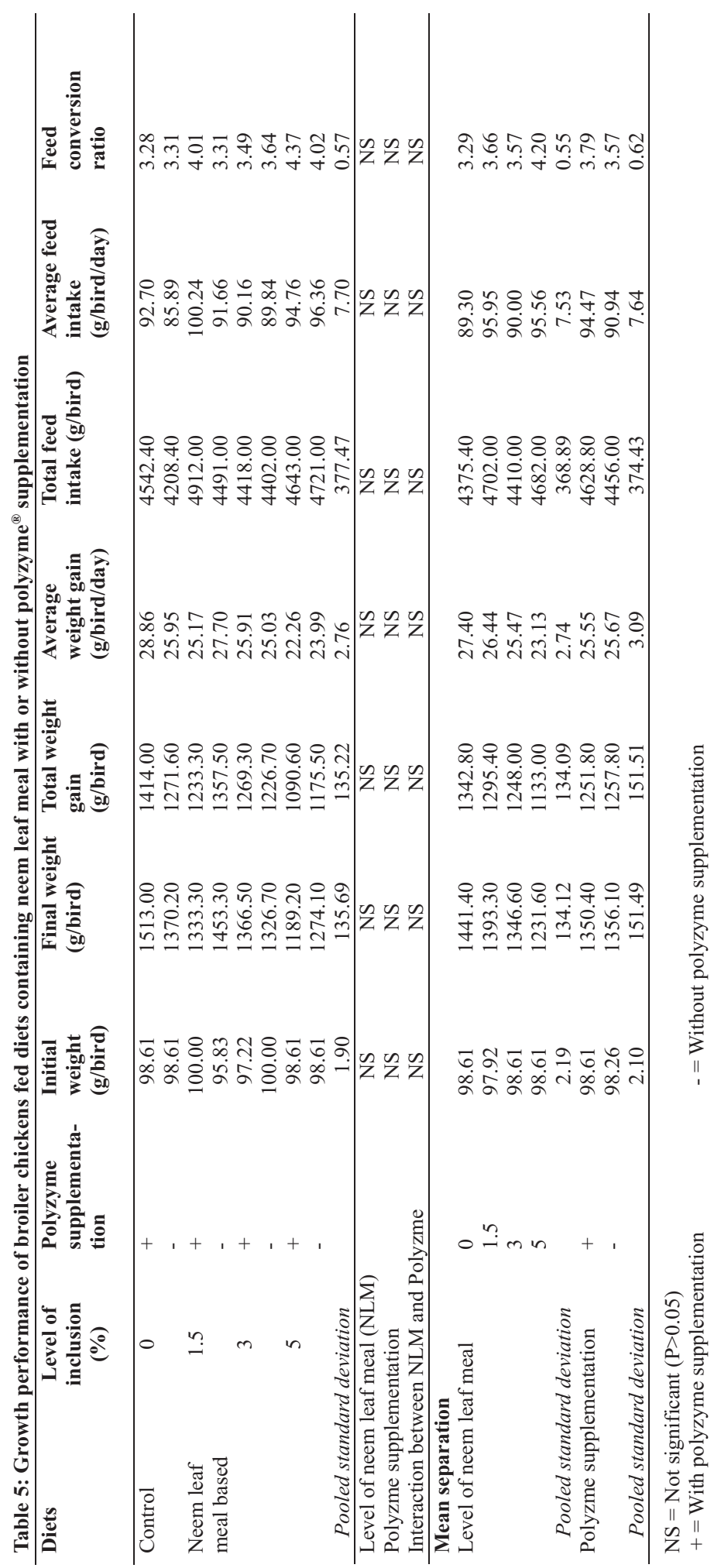




\section{Akintomide, Osho and Onibi}

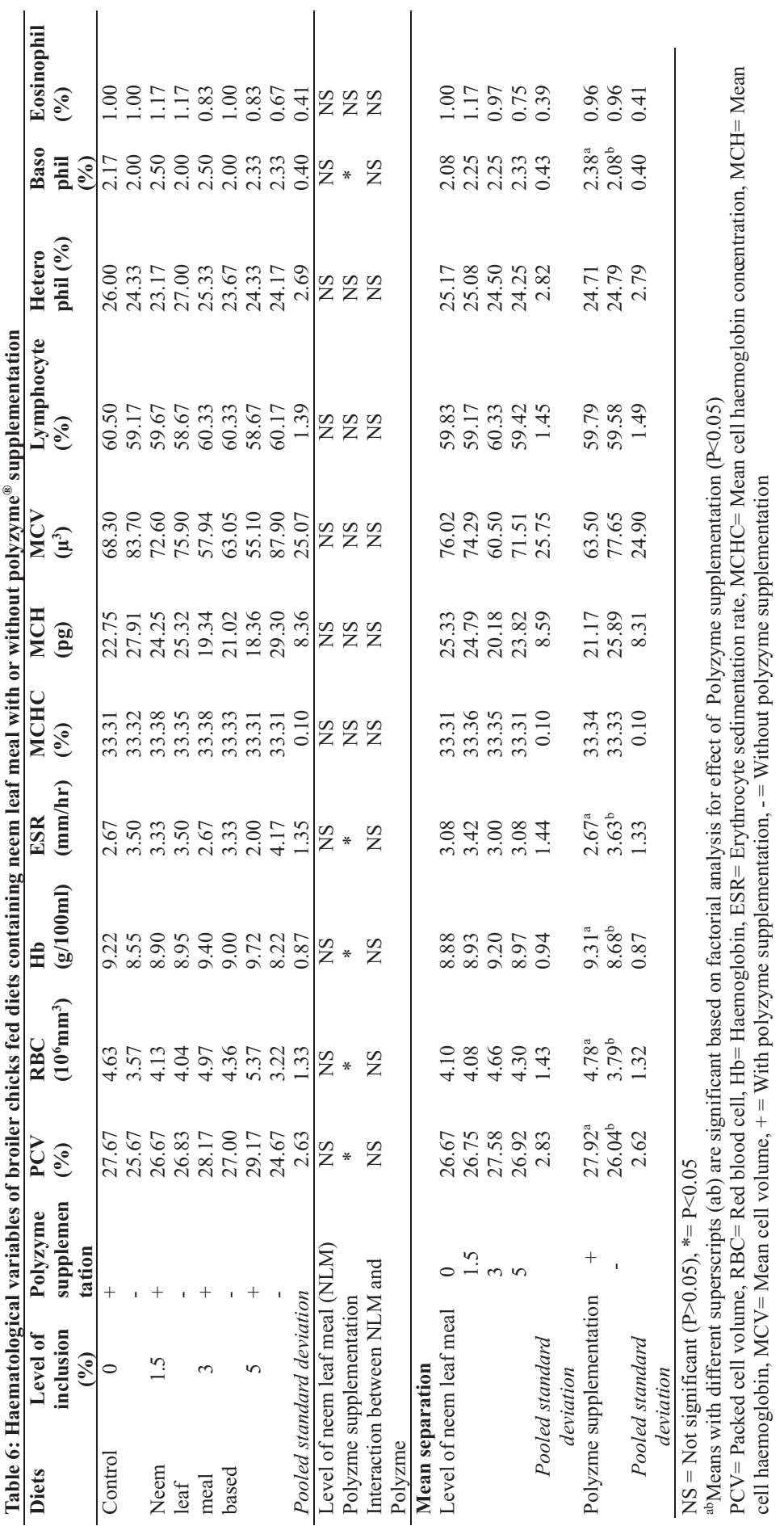


Growth performance and haematology of broiler chickens fed enzyme supplemented neem leaf meal

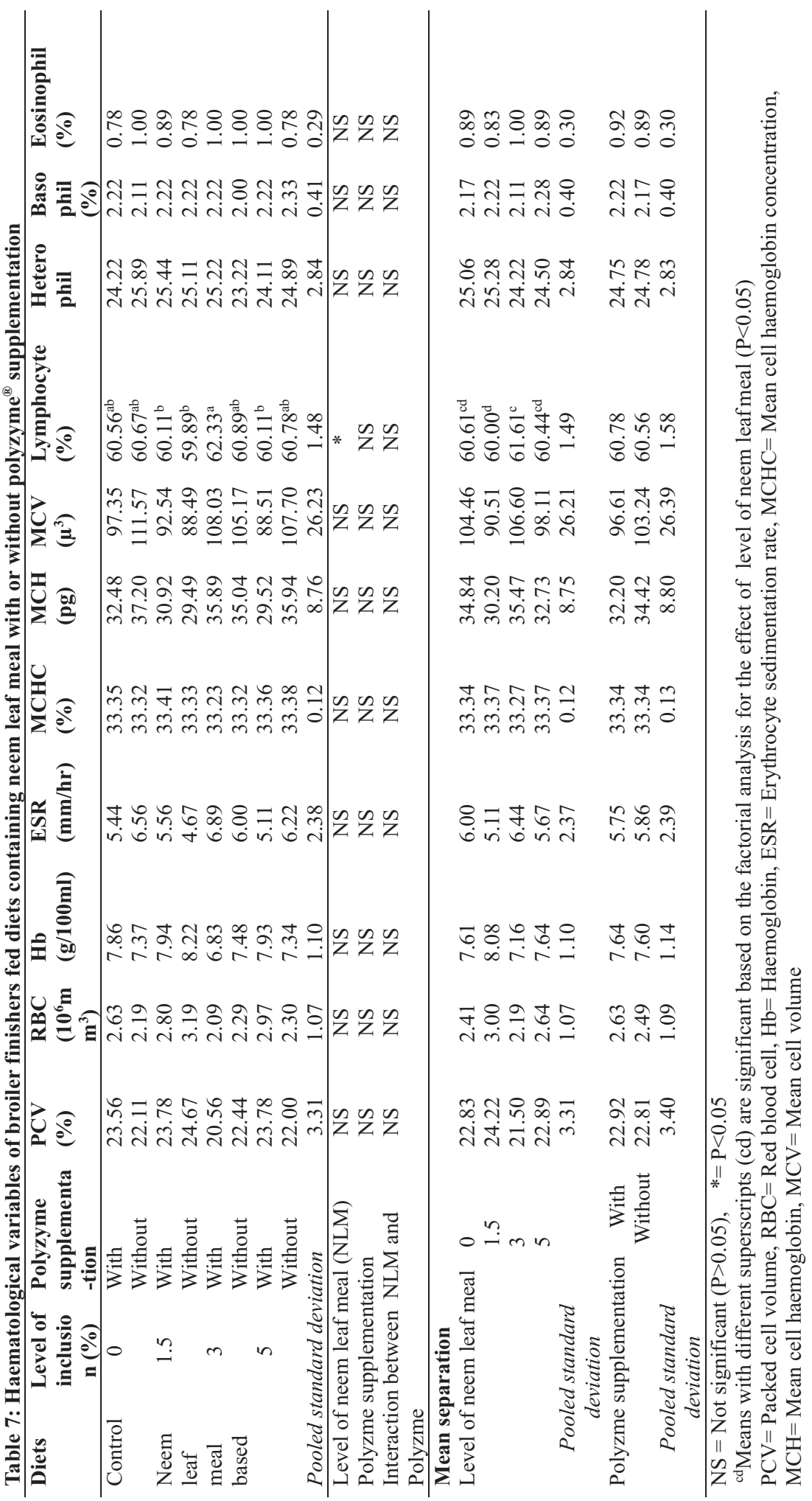




\section{Akintomide, Osho and Onibi}

\section{Discussion}

The observed effects of polyzyme ${ }^{\circledR}$ on the growth parameters of the chicks might infer that there was no improvement in the utilization of the feed at the level of $400 \mathrm{~g} /$ tonne used in this study. However, no difference in level of NLM was observed when the assessment of final weight and total weight gain was done at the finisher phase and overall possibly because older birds have more developed digestive system. This suggests that values below 5\% should be considered when NLM is to be used in broiler chickens diets.

Obikaonu (2012) also observed significant difference in final weights of finishers given control and 5\% NLM diet. Onyimonyi et al. (2009) however suggested inclusion level of $0.5 \%$. Polyzyme ${ }^{\circledR}$ as a multi-enzyme contains xylanase, phytase, cellulase, $\beta$ glucanase, pectinase, $\alpha$-amylase, protease, $\alpha$-galactosidase, $\beta$-galactosidase, lipase and mannanase. According to Manafi et al. (2011), the use of polyzyme ${ }^{\circledR}$ elicited a nonsignificant and marginal improvement in the final weights of broilers fed corn bran diets when reared up to 8 weeks. Also, when Fabunmi et al. (2019) used polyzyme ${ }^{\circledR}$ in diets which had maize partially replaced with kolanut husk, no significant improvement in broiler weight gain was observed. Furthermore, Sunmola et al. (2018) found no difference in final body weight and weight gain of broilers fed sweet orange peel meal diets with or without polyzyme $^{\circledR}$ supplementation. So, the submission of Duru and Dafwang (2010) that maxigrain ${ }^{\circledR}$ supplementation did not improve an isocaloric and isonitrogenous diet but did improve the utilization of low energy diet might be applicable. Also, according to Bedford and Schulze (1998), factors like source of enzyme, variety of unconventional feedstuff, age and health status of the animal affect the response of such animal to feed supplemented with enzymes. As such, increase in the quantity of Polyzyme to be incorporated in fibrous feedstuffs might be considered. Haematology is valuable in assessing the physiological responses of chickens (Khan and Zafar, 2005). And as noted earlier, packed cell volume (PCV) and haemoglobin concentration $(\mathrm{Hb})$ are two parameters of high significance in determining their health status. The parameters were not affected by level of NLM up to $5 \%$ at the starter phase. Although, the values were significantly different based on polyzyme supplementation, both values were still within the ranges $(\mathrm{PCV}=25-45 \% ; \mathrm{Hb}=7$ $13 \mathrm{~g} / 100 \mathrm{ml}$ ) described for healthy birds by Mitruka and Rownsley (1977) and Ross et al. (1978) and PCV range of 22-43\% by Orawan and Aengwanich (2007). Fabunmi et al. (2019) however did not record significant effect of polyzyme supplementation on PCV and $\mathrm{Hb}$ of broilers fed kolanut husk meal. The significance seen in lymphocyte values based on levels of NLM were slight and did not follow any trend with increase/ decrease in inclusion level and the values fell within the reference range. In line with this result, Bonsu et al. (2012) did not record significance in $\mathrm{Hb}$ of birds fed NLM up to $2.5 \%$. Hence, inclusion of up to $5 \%$ NLM in broiler diets did not predispose them to anaemia.

\section{Conclusion}

The study showed that broiler starters could tolerate up to $3 \%$ neem leaf meal and finishers up to $5 \%$ based on growth performance. The enzyme (Polyzyme ${ }^{\circledR}$ ) used at $400 \mathrm{~g} /$ tonne did not improve the utilization of neem leaf meal by the broilerchickens. The two parameters of high significance in determining the health status of birds which are packed cell volume and haemoglobin concentration were not affected by level of neem leaf meal (up to $5 \%)$. 
References

Adebayo, O. O. and Adeola, R. G. 2005. Socio-economics factors affecting poultry farmers in Ejigbo Local Government Area of Osun State. Journal of Human Ecology, 18(1): 39-41.

Adesua, A. A. 2019. Chemical characterization and effects of neem (Azadirachta indica a. Juss) and sweet potato (Ipomoea batatas L. Lam) leaf meals on performance and meat quality of broilerchickens (Unpublished doctoral thesis). Federal University of Technology, Akure, Nigeria.

Ajila, C. M., Brar, S. K., Verma, M., Tyagi, R. D., Godbout, S. and Valero, J. R. 2012. Bio-processing of agro-byproducts to animal feed. Critical Reviews in Biotechnology, 32(4): 382-400.

Alam, M. J., Howlider, M. A. R., Pramanik, M. A. H. and Haque, M. A. 2003. Effect of exogenous enzyme in diet on broiler performance. International Journal of Poultry Science, 2 (2): 168-173.

Allouche, L., Madani, T., Ait Hamouda, Z., Boucherit, M. R., Taleb, H., Samah, O., Rahmani, K. and Touabti, A. 2015. Effect of addition of exogenous enzymes in hypocaloric diet in broiler chicken on performance, biochemical $\mathrm{p}$ a ram e ters a nd meat characteristics. Biotechnology in Animal Husbandry, 31(4): 551565.

Bedford, M. R. and Schulze, H. (1998). Exogenous enzymes for pigs and poultry. Nutrition Research Reviews, 11:91-114.

Bonsu, F. R. K., Kagya-Agyemang, J. K., Kwenin, W. K. J. and Zanu, H. K. 2012. Medicinal response of broiler chickens to diets containing neem (Azadirachta indica) leaf meal, haematology and meat sensory analysis. World Applied Sciences Journal, 19(6): 800-805.

Costa, F. G. P., Goulart, C. C., Figueiredo, D. F., Oliveira, C. F. S. and Silva, J. H. V. 2008. Economic and environmental impact of using exogenous enzymes on poultry feeding. International Journal of Poultry Science, 7:311-314.

Duru, S. and Dafwang, I. I. 2010. Effect of maxigrain supplementation of diets with or without rice offal on the performance of broiler chicks. International Journal of Poultry Science, 9: 761-764.

Fabunmi, T. B., Arotupin, D. J., Adegunloye, D. V., Orunmuyi, M. and Ododle, B. S. 2019. Effects of kolanut husk formulated feed at graded levels on growth performance and health of Ross broilers with or without enzyme inclusion. Acta Scientific Agriculture, 3(2): 105-113.

Fasuyi, A. O. 2007. Amaranthus cruentus leaf meal as a protein supplement in broiler finisher diets part 2: haematological responses, carcass characteristics and relative organ weights. African Journal of Food, Agriculture, Nutrition and Development, 7(6): 6.

Hien, T. Q., Hoan, T. T., Kien, T. T. and Trung, T. Q. 2017. The effect of some leaf meal kinds as a supplement in the basal diet on Luong Phuong broiler performance. Bulgarian Journal of Agricultural Science, 23(4): 617624.

Khan, A. T. and Zafar, F. 2005. Haematological study in response 
to varying doses of estrogen in broiler chicken. International Journal of Poultry Science, 40(10): 748-757.

Kumar, P. S., Mishra, D., Ghosh, G. and Panda, C. S. 2010. Biological action and medicinal properties of various constituent of Azadirachta indica (Meliaceae)" an Overview. Annals of Biological Research, 1(3): 24-34.

Lamb, G. N. 1981. Manual of veterinary laboratory techniques CJBAGeigy, Kenya. pp 92-109.

Manafi, M., Bagheri, H. and Yazdani, M. 2011. Effect of polyzyme in broilers fed corn (Zea mays L.) bran-based diets. Advances in Environmental Biology, 5(7): 1651-1655.

Obikaonu, H. O. 2012. Evaluation of the nutritional value of neem (Azadirachta indica) leaf meal on the performance of finisher broilers. International Journal of Agriculture and Rural Development, 15(3):1235-1239.

Ogunsipe, M. H., Adejumo, J. O., Agbede, J. O. and Asaniyan, E. K. 2015. Effect of roxaazyme G2G supplementation on cassava plant meal fed to broiler chickens. Livestaock Reasearch for Rural Development, 27: Article 240.

Onyimonyi, A.E., Olabode, A. and Okeke, G.C. 2009. Performance and economic characteristics of broilers fed varying dietary levels of neem leaf meal (Azadirachta indica). International Journal of Poultry Science, 8(3): 256-259.

Orawan, C. and Aengwanich, W. 2007.
Blood cell characteristics, haematological values and average daily gained weight of Thai indigenous, Thai indigenous crossbred and broiler chickens. Pakistan Journal of Biological Science, 10:302-309.

Oyinloye, M. A. 2013. Monitoring spatial growth of educational institution using geographical information system: a focus on Federal University of Technology, Akure, Nigeria. American Journal of Humanities and Social Sciences, 1(3): 163-173.

Sithisarn, P., Supabphol, R. and Grits a n a a n, W. 2005 . Antioxidant activity of Siamese neem tree (VP 1209). Journal of Ethnopharmacology, 99:109-112.

Sunmola, T. A., Tuleun, C. D. and Oluremi, O. I. A. 2018. Performance characteristics of starter broiler chicks fed dietary sun-dried sweet orange peel meal (SOPM) with and without polyzyme $^{\circledR}$. Scientific Research Journal, 6(8): 89-97.

Received: $14^{\text {th }}$ May, 2021 Accepted: $15^{\text {th }}$ August, 2021 